\title{
PERENCANAAN BISNIS FASHION HIJAB
}

\author{
Anita \\ Program Studi Magister Manajemen Universitas Tarumanagara \\ anitasutiono@gmail.com
}

\begin{abstract}
Perencanaan Bisnis Fashion Hijab" is a business plan in the field of creative industries. With many of Muslim communities, it is an opportunity for startup to plan the business, especially in the Hijab fashion industry. This business plan aims to create a new business plan for the creative industry engaged in fahion hijab and creating investment opportunities for investors. Based on the results of the analysis and discussion, it can be concluded that this business is feasible to be realized on the basis of consideration, among others, because the market potential of the hijab fashion business is increasing. Financial planning that shows this business will provide profit for investors and is worthy of being realized. Analysis of financial instruments consisting of a payback period which shows the number 4 equal to the maximum time set, the Net Present Value value with a value of Rp. $522,051,842$, - or greater than zero indicates this investment can produce an income level that exceeds the requested level and an Internal Rate of Return value of $35 \%$ higher than the deposit interest rate.
\end{abstract}

Abstrak: "Perencanaan Bisnis Fashion Hijab" adalah rencana bisnis usaha di bidang industri kreatif. Dengan lahirnya banyak komunitas muslim ini, maka merupakan peluang bagi para start-up untuk merencanakan bisnis fahion, khususnya pada Hijab. Perencanaan bisnis ini bertujuan untuk membuat suatu rencana bisnis baru pada industri kreatif yang bergerak di bidang fahion hijab dan menciptakan kesempatan investasi bagi investor serta menghasilkan profit yang menguntungkan. Berdasarkan hasil analisa dan pembahasan, maka dapat disimpulkan bahwa bisnis ini layak direalisasikan dengan dasar pertimbangan antara lain karena potensi pasar bisnis fashion hijab meningkat. Perencanaan keuangan yang menunjukan bahwa bisnis ini akan memberikan profit bagi investor dan layak untuk direalisasikan. Analisa instrument keuangan yang terdiri dari Payback Period yang menunjukan angka 4 sama dengan waktu maksimal yang ditetapkan, nilai Net Present Value dengan nilai Rp. 522,051,842,- atau lebih besar dari nol menunjukan investasi ini dapat menghasilkan tingkat penghasilan yang melebihi tingkat yang diminta dan nilai Internal Rate of Return sebesar 35\% lebih tinggi dari suku bunga simpanan.

Keywords: Fashion Hijab, Business Plan, Payback Period, Net Present Value, Internal Rate of Return.

\section{PENDAHULUAN}

Indonesia menyadari bahwa ekonomi kreatif, yang berfokus pada penciptaan barang dan jasa dengan mengandalkan keahlian, bakat, dan kreativitas sebagai kekayaan intelektual, adalah harapan bagi ekonomi Indonesia untuk bangkit, bersaing dan meraih keunggulan dalam ekonomi global. Ekonomi kreatif termasuk di antaranya itu pada bidang fashion, yang mana fashion bukan lagi hanya menjadi kebutuhan primer sebagai penutup , tetapi telah menjadi kebutuhan mode/gaya/tren. Dengan mayoritas penduduk muslim di Indonesia, gaya hidup Islami merupakan suatu perkembangan yang sangat di minati. Banyaknya penduduk muslim di Indonesia cukup memberi banyak pengaruh terhadap bisnis. Hal itu terlihat dari banyaknya bisnis yang kini berlomba membuat produk syariah. Salah satu faktor pendorong pertumbuhan bisnis syariah adalah tren pemakaian hijab yang belakangan ini telah menjadi lifestyle. Menurut Dirjen Industri Kecil Menengah (IKM) Kementerian Perindustrian Euis 
Saidah, terdapat 20 juta penduduk Indonesia yang menggunakan hijab. Hal ini selaras dengan perkembangan industri fashion muslim $7 \%$ pertahun. Indonesia diprediksikan menjadi kiblat fashion muslim dunia di tahun 2020 mendatang. Hal ini diberitakan oleh Indonesia Islamic Fashion Consortium (IIFC).

Menurut mantan Wakil Menteri Pariwisata dan Ekonomi Kreatif Sapta Nirwandar, Indonesia memiliki potensi sebagai salah satu pusat mode dunia khususnya untuk busana muslim, karena Indonesia memiliki sumber daya kreatif dan warisan budaya yang melimpah. Di masa depan Indonesia bisa menjadi sumber inspirasi untuk pengembangan mode dunia. Sapta mengatakan, targetnya pada tahun 2020 nanti Indonesia sudah menjadi kiblat busana muslim dunia. Menurutnya, Indonesia memiliki keunggulan pada warna-warna busana yang cantik, desain unik, serta penggabungan kain-kain tradisional. Produk busana muslim yang berkualitas ini tentunya perlu disampaikan dengan baik kepada pasar, baik lokal maupun dunia. Beragam faktor membuat fashion muslim terus berkembang. Hal itu terlihat dari terus naiknya permintaan busana muslim, tumbuhnya komunitas-komunitas hijab seperti Hijabers Community, Hijabers Mom, dan lain-lain sampai diselenggarakannya beragam bazar, peragaan busana muslim, kegiatan hijab class di kampus, perusahaan, pengajian, ataupun arisan. Dengan lahirnya banyak komunitas muslim ini, maka ada peluang bagi para start-up untuk merencanakan bisnis fahion, khususnya pada Hijab. Oleh karena itu penulis penulis merasa sangat tertarik untuk melakukan pembuatan tesis ini yang berhubungan dengan rencana bisnis usaha dibidang industri kreatif, bidang fashion, dengan judul "PERENCANAAN BISNIS FASHION HIJAB".

\section{Tujuan}

Penulisan thesis perencanaan bisnis ini bertujuan untuk :

- Membuat suatu rencana bisnis baru pada industri kreatif yang bergerak di bidang fahion hijab.

- Menciptakan kesempatan investasi bagi investor serta menghasilkan profit yang menguntungkan.

- Membuka lapangan kerja untuk meningkatkan taraf hidup masyarakat.

\section{RINGKASAN EKSEKUTIF \\ Product, Price, Place \& Promotion (4P) \\ Product, Price}

Philip Kotler (2012) menyebutkan bahwa "Product is anything that can be offered to someone to satisfy a need or a want." Selain itu William Stanton (2009) juga menjelaskan definisi produk, yaitu "Product is complex of tangible and intangible attributes, including packaging, colour, price, prestige, and services, that satisfy needs and wants of people." Produk utama yang ditawarkan adalah Hijab. Produk kami berfokus pada satu tujuan yaitu kami memastikan kosumen mendapatkan pengalaman dan kepuasan pelanggan yang maksimal. Menurut Kotler dan Armstrong (2012:314) harga adalah "The amount of money charged for a ptoduct or service, the sum of the values that customers exchange for the benefit of having or using the product or service". Definisi lain dikemukakan oleh Buchari Alma (2011:169), mengemukakan bahwa harga adalah nilai suatu barang yang dinyatakan dengan uang. Sedangkan menurut Djaslim Saladin (2010 : 159) mengemukakan bahwa harga adalah komponen yang menghasilkan pendapatan sedangkan yang lainnya menghasilkan biaya.

Menurut Tjiptono (2011:151) menyebutkan bahwa harga meruakan satu-satunya unsur bauran pemasaran yang memberikan pemasukan atau pendapatan bagi perusahaan.

Place

Definisi menurut Philip Kotler mengenai distribusi adalah : "The various the company undertakes to make the product accessible and available to target customer". Berbagai 
kegiatan yang dilakukan perusahaan untuk membuat produknya mudah diperoleh dan tersedia untuk konsumen sasaran.

Tempat operasional kamu berlokasi di Jalan Cendrawasih 8 No 1, Kranggan Permai, Jatisampurna, Bekasi. Lokasi yang berada di perumahan ini menjadi tempat pengemasan produk untuk menjadi produk ready to sell. Untuk proses pembuatan produk hijab berlokasi di Pasar Raya Kranggan.

\section{Promotion}

Promosi atau promotion merupakan teknik komunikasi yang penggunaannya atau penyampaiannya menggunakan media seperti: pers, televisi, radio, papan nama, poster dan lain-lain, yang tujuannya untuk menarik minat konsumen terhadap hasil produksi suatu perusahaan. Promosi adalah satu dari 7P dalam bauran pemasaran jasa. Kotler Armstrong (2013: 76) mendefinisikan promosi sebagai, "Promotion means activities that communicate the merits of the product and persuade target customers to buy it".

Sementara itu menurut Belch Belch (2009: 18) promotion didefinisikan sebagai "Promotion has been defined as the coordination of all seller initiated efforts to set up channels of information and persuasion in order to sell goods and services or promote an idea." Widiyono dan Pakkanna (2013:148) mendefinisikan promosi adalah teknik-teknik atau berbagai cara yang dirancang untuk menjual produk atau pesan yang disampaikan perusahaan kepada konsumen tentang produknya. Di sisi yang lain menurut Tjiptono (2008:229) promosi penjualan adalah bentuk persuasi langsung melalui penggunaan berbagai insentif yang dapat diatur untuk merangsang pembelian produk dengan segera dan meningkatkan jumlah barang yang dibeli pelanggan.

\section{Rencana Bisnis \\ Segmentation, Targeting \& Positioning Segmentation}

Menurut Kotler dan Keller (2012) segmentasi pasar adalah sebuah proses di mana membagi sebuah pasar menjadi beberapa kelopmpok pembeli yang memiliki kebutuhan karakteristik atau perilaku yang berbeda, dan pembeli yang mungkin memerlukan produk yang berbeda/ terpisah atau program pemasaran yang berbeda. Tugas pemasar adalah mengidentifikasi segmen dan memutuskan segmen mana yang akan dibidik bisnis ini.

Segmentasi bisnis ini ada pada konsumen kalangan menengah ke atas. Untuk Hijab Premium akan kami targetkan untuk komunitas Hijaber kalangan atas, yang tentunya telah memiliki penghasilan sendiri.

Untuk produk square, pashmina dan organza akan ditargetkan untuk segment menengah.

\section{Targeting}

Menurut Kotler dan Keller (2012) market targeting adalah sebuah proses mengevaluasi ketertarikan masing-masing segmen pasar dan memilih satu atau lenih segmen pasar untuk dimasukin perusahaan.

\section{Positioning}

Kotler dan Keller (2012) menyebutkan definisi dari positioning adalah mengatur sebuah produk untuk menempati posisi yang jelas, khas, dan diinginkan untuk bersaing dengan produk yang relatif untuk menempatkan produk perusahaan di benak sasaran konsumen yang diinginkan perusahaan. Pemasar berencana mengatur posisi produk mereka untuk dapat bersaing dengan produk sejenis.

Kami akan memposisikan produk kami dengan harga yang terjangkau dan tetap menjaga kualitas produk. Dengan menempatkan produk ini pada produk unik dan sukar dicari di tempat lain. 


\section{Kebutuhan Investasi dan Modal Kerja}

Perencanaan keuangan bertujuan untuk memberikan gambaran seberapa besar potensi keuntungan dari bisnis tersebut dan untuk memantau kinerja perusahaan dari sisi keuangan yang digunakan dalam mengambil keputusan berkaitan dengan kebijakan finansial maupun operasional perusahaan.

Total modal kerja yang diperlukan untuk memulai bisnis ini adalah Rp.315,599,000.- yang di mana kami harapkan dengan total investor sebanyak 4 (empat) orang dengan masing-masing nilai investasi sebesar $25 \%$ atau setara dengan Rp.315,599,000.-

\begin{tabular}{|c|c|c|c|c|}
\hline \multicolumn{3}{|c|}{ (Dalam Rupiah) } & \multirow{2}{*}{$\begin{array}{l}\text { (Dalam Rupiah) } \\
\text { Liabilitas }\end{array}$} & \\
\hline \multirow[t]{4}{*}{ Aktiva } & & & & \\
\hline & Aktiva Lancar & & Utang Usaha & - \\
\hline & Kas di Bank & $50,000,000$ & \multirow{2}{*}{ Total Utang Lancar } & \\
\hline & $\begin{array}{l}\text { Sewa dibayar } \\
\text { dimuka }\end{array}$ & $180,250,000$ & & - \\
\hline & & & & \\
\hline & \multirow[t]{2}{*}{$\begin{array}{l}\text { Total } \\
\text { Lancar }\end{array}$} & $230,250,000$ & Ekuitas & \\
\hline & & & \multicolumn{2}{|l|}{ Setor Modal Awal AKOYA } \\
\hline & Aktiva Tetap & & Investor 1 & $78,899,750$ \\
\hline & \begin{tabular}{l|l} 
Bangunan \\
(Non \\
permanen)
\end{tabular} & $25,000,000$ & Investor 2 & $78,899,750$ \\
\hline & Kendaraan & $16,600,000$ & Investor 3 & $78,899,750$ \\
\hline & Peralatan & $21,749,000$ & Investor 4 & $78,899,750$ \\
\hline & $\begin{array}{l}\text { Aktiva lain- } \\
\text { Lain }\end{array}$ & $22,000,000$ & $\begin{array}{l}\text { Total Modal Akhir } \\
\text { AKOYA }\end{array}$ & $315,599,000$ \\
\hline & $\begin{array}{l}\text { Total Aktiva } \\
\text { lancar }\end{array}$ & $85,349,000$ & & \\
\hline \multicolumn{2}{|c|}{ Total Aktiva } & $315,599,000$ & $\begin{array}{l}\text { Total Liabilitas dan } \\
\text { Ekuitas }\end{array}$ & $315,599,000$ \\
\hline
\end{tabular}

Table Neraca Saldo

\section{Payback Period (PP)}

Suliyanto (2010) menjelaskan bahwa "Payback Period merupakan metode yang digunakan untuk menghitung lama periode yang diperlukan untuk mengembalikan uang yang telah diinvestasikan dari aliran kas masuk (proceeds). Apabila proceeds setiap tahunnya jumlahnya sama maka payback period (PP) dari suatu investasi dapat dihitung dengan cara membagi jumlah investasi dengan proceeds tahunan" (p.196).

Table 1 Payback Period

\begin{tabular}{|l|l|l|}
\hline Tahun & Nett Cashflow & Proceed \\
\hline 2019 & $86,459,319.35$ & $86,459,319.35$ \\
\hline 2020 & $149,097,451.28$ & $235,556,770.63$ \\
\hline 2021 & $230,748,486.41$ & $466,305,257.04$ \\
\hline 2022 & $333,158,112.10$ & $799,463,369.14$ \\
\hline 2023 & $468,122,411.62$ & $1,267,585,780.76$ \\
\hline
\end{tabular}

*Asumsui kenaikan laba $25 \%$ per tahun setelah 2023

Tahun 2

Tahun terakhir dimana jumlah 


\begin{tabular}{|l|l|l|}
\hline terakhir & & $\begin{array}{l}\text { arus kas masih belum bisa } \\
\text { menutup investasi mula-mula }\end{array}$ \\
\hline a & $315,599,000$ & Jumlah investasi mula-mula \\
\hline b & $235,556,770.63$ & $\begin{array}{l}\text { Jumlah kumulatif arus kas pada } \\
\text { tahun ke }-\mathrm{n}\end{array}$ \\
\hline c & $466,305,257.04$ & $\begin{array}{l}\text { Jumlah kumulatif arus kas pada } \\
\text { tahun ke }+\mathrm{n}\end{array}$ \\
\hline
\end{tabular}

Payback Period $=\quad n+(a+b) /(c-b)=\mathbf{4 . 3 9}$

\section{Net Present Value (NPV)}

Net Present Value (NPV) membandingkan nilai sekarang arus kas di masa depan yang diharapkan berasal dari proyek investasi dengan pengeluaran kas awal untuk investasi tersebut.

Table 2 Net Present Value (NPV)

\begin{tabular}{|l|l|c|r|}
\hline Tahun & Nett Cashflow & DF (12\%) & PV \\
\hline 2018 & $(315,599,000)$ & 1.0000 & $(315,599,000)$ \\
\hline 2019 & $86,459,319$ & 0.8929 & $77,195,821$ \\
\hline 2020 & $149,097,451$ & 0.7972 & $118,859,575$ \\
\hline 2021 & $230,748,486$ & 0.7118 & $164,242,215$ \\
\hline 2022 & $333,158,112$ & 0.6355 & $211,728,003$ \\
\hline 2023 & $468,122,412$ & 0.5674 & $265,625,228$ \\
\hline \multicolumn{2}{|l|}{ NPV Positif }
\end{tabular}

\section{Internal Rate of Return (IRR)}

Internal Rate of return (IRR) adalah tingkat pengembalian internal atau pengembalian yang berasal dari suatu usulan proyek tertentu. IRR adalah tingkat diskonto yang membuat nilai sekarang bersih arus kas masuk sama dengan nilai sekarang bersih arus kas keluar sama dengan nol.

Table 3 Internal Rate of Return

\begin{tabular}{|l|l|l|l|l|r|}
\hline Tahun & $\begin{array}{l}\text { Nett } \\
\text { Cashflow }\end{array}$ & $\begin{array}{l}\text { DF } \\
(\mathbf{1 5 \%})\end{array}$ & PV (15\%) & $\begin{array}{l}\text { DF } \\
\mathbf{( 1 5 \% )}\end{array}$ & PV(17\%) \\
\hline 2018 & $(315,599,000)$ & 1.0000 & $(315,599,000)$ & 1.0000 & $(315,599,000)$ \\
\hline 2019 & $86,459,319$ & 0.8696 & $75,182,017$ & 0.8547 & $73,896,854$ \\
\hline 2020 & $149,097,451$ & 0.7561 & $112,739,094$ & 0.7305 & $108,917,709$ \\
\hline 2021 & $230,748,486$ & 0.6575 & $151,720,875$ & 0.6244 & $144,072,561$ \\
\hline 2022 & $333,158,112$ & 0.5718 & $190,484,232$ & 0.5337 & $177,789,843$ \\
\hline 2023 & $468,122,412$ & 0.4972 & $232,739,572$ & 0.4561 & $213,515,853$ \\
\hline
\end{tabular}




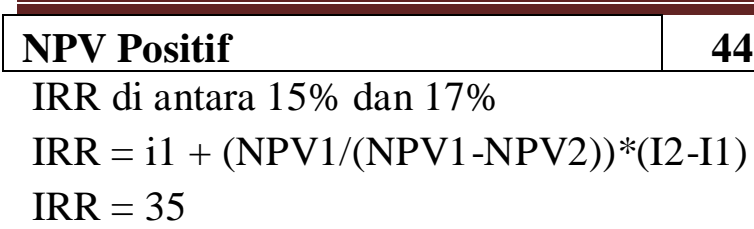

\section{KESIMPULAN}

Perencanaan keuangan yang menunjukan bahwa bisnis ini akan memberikan profit bagi investor dan layak untuk direalisasikan. Analisa instrument keuangan yang terdiri dari payback period yang menunjukan angka 4 sama dengan waktu maksimal yang ditetapkan, nilai NPV dengan nilai Rp. 522,051,842,- atau lebih besar dari nol menunjukan investasi ini dapat menghasilkan tingkat penghasilan yang melebihi tingkat yang diminta dan nilai IRR sebesar 35\% lebih tinggi dari suku bunga simpanan menunjukan bahwa bisnis ini layak untuk diinvestasikan dan dijalankan.

\section{DAFTAR PUSTAKA}

Latiff \& Yusof.(2016). A methodology for facial measurement towards the establishment of ready-to-wear hijab sizing.International Journal of Clothing Science and Technology, 28, 841-853.

Kotler dan Keller. 2009. Manajemen Pemasaran. Jilid I. Edisi ke 13 Jakarta: Erlangga

Kotler, Philip and Gary Armstrong. 2012. Prinsip-prinsipPemasaran. Edisi13. Jilid 1. Jakarta: Erlangga.

Buchari Alma. 2011. Manajemen Pemasaran dan Pemasaran Jasa. Bandung : Penerbit Alfabeta.

William J. \& Stanton (2009).Prinsip Pemasaran.jilid I.Jakarta.Erlangga.

Fandy, Tjiptono,(2011), Pemasaran Jasa, Bayumedia, Malang.

Belch, George E., Belch, Michael A. (2009). Advertising and Promotion : An Integrated Marketing Communication Perpective. 8th Edition. New York : McGraw-Hill

Widiyono dan Mukhaer Pakkanna. 2013. Pengantar Bisnis : Respon terhadap Dinamika Global. Mitra Wacana Media. Jakarta.

Tjiptono, Fandy, 2008, Strategi Pemasaran, Edisi 3, ANDI: Yogyakarta. 
